\title{
Safe Medicine Administration Counseling for Pregnant and Breastfeeding Mothers
}

\author{
Nurhidayati Haruna), Firdawati, and Nia Kurniasih \\ Program Studi Farmasi, STIKes Muhammadiyah Ciamis, Ciamis, Indonesia \\ a)Corresponding Author: harunnurhidayati@gmail.com
}

\begin{abstract}
The use of drugs for pregnancy and breastfeeding needs to be self-medication and the importance of counselling to increase the mother's knowledge about the correct use of drugs so that pregnant and lactating women's level of health and knowledge increases. The counselling purpose was to determine the mother's level of knowledge and whether there was a difference in the knowledge level of the use of drugs during pregnancy and lactation. The method used is pre and post-media analysis (flipchart). Data analysis obtain by scoring questionnaires, univariate analysis, and statistical analysis. Mann-Whitney test results showed that in the post-test or after giving counselling using flipchart media, there was a change in respondents' knowledge from before being given a flipchart and after being given a flipchart. The hypothesis from this counselling is accepted, which means that giving flipcharts affects the level of knowledge. The calculations using the spearman test obtained $p$-value pretest 0.732 and $p$-value post-test 0.253 for pregnant women and obtained $p$-value pretest and post-test of $0.033(p<0.05)$ for breastfeeding mothers, then there is a relationship between the education level pregnant and lactating mothers with knowledge. The Wilcoxon test data pretest and post-test knowledge of pregnant and lactating mothers had a p-value of 0.003 ( $p$ 0.05), the effect of counselling concluded with flipchart media on the knowledge of pregnant and lactating mothers about the use of drugs.
\end{abstract}

Keywords: Counselling, knowledge, pregnant and breastfeeding mothers, flipchart

\section{INTRODUCTION}

Counselling is an activity of educating individuals or groups, providing knowledge, information, and various abilities to form attitudes and behaviour in life that should be. In essence, counselling is a non-formal activity to change society towards a better state as aspired (Maulana et al., 2019). Knowledge is the result of human sensing, or someone knowing about objects through their senses (eyes, nose, ears). Moreover, most of a person's knowledge obtaining through the sense of hearing (ears) and sight (eyes). A person's knowledge of objects has different intensities or levels. The knowledge is divide into six levels of knowledge (Ratih \& Yudita, 2019).

Currently, education about the safety of drug use in pregnant and lactating women needs to be encouraged to avoid unwanted effects on the nation's future generation. According to the Directorate of Community and Clinical Pharmacy Development, pregnancy, childbirth, and breastfeeding are physiological processes that need to be prepared by women from fertile couples passed safely. Many pregnant women use drugs and supplements during the organogenesis period, resulting in a greater risk of fetal defects. Drug administration must also pay attention to drug toxicity reactions (Harun et al., 2017) and the incidence of congenital disabilities due to drug use during pregnancy, which reaches 2-3\% of birth events. (Anita, 2017). Counselling has a significant role in reducing the incidence of disability. That increased the knowledge level by $25.73 \%$ from the value of initial knowledge after the education process using a flipchart (Raikar et al., 2020).

\section{METHOD}

In Sumberjaya Village, Cihaurbeuti District, this counselling was obtained from 30 mothers (15 pregnant women and 15 breastfeeding mothers). Each participant gives a flipchart to facilitate acceptance given by the extension worker. All participants evaluate their level of 
knowledge using the one-group pretest-posttest design technique to see their level of knowledge, Ciamis Regency. The media used in this research is a flipchart.

The counselling participants whose knowledge level will evaluate are selected based on inclusion and exclusion criteria. All participants voluntarily participated in this assessment, as evidenced by signing the informed consent. After 15 days, the first pretest was carrying, and the next 15 days was the second posttest. Then do the data analysis.

After the data is entered and analyzed, the data processing results are presented and interpreted in the form of a report, then a discussion of the research results is carried out, and draws conclusions and makes suggestions or recommendations referring to the counselling results that have been carrying.

\section{RESULTS}

Test the validity of the knowledge level questionnaire.

Pearson colleration results obtained numbers $0.942,0.940,0.940,0.940,0.940,0.942,0.940$, $0.940,0.942,0.724,0.672,0.739,0.624,0.514,0.736,0.645,0.629,0.540$ (table 1).

\section{Knowledge level reliability test}

The results of the questionnaire reliability test for the knowledge questionnaire obtained Chronbach's alpha value of 0.975 .

\section{Characteristics of Respondents}

Based on the frequency distribution data result of respondents according to age groups, namely the age of 20-27 years who came to attend the counselling as many as eight respondents (53.3\%) and aged $28-35$ years, namely as many as seven respondents (46.7\%).

Based on the data are seen in the frequency distribution of respondents according to education, namely elementary education as many as four respondents (26.7\%), junior high school education who participated in counselling the most were six respondents $(40.0 \%)$, high school education four respondents (26.7\%), and diploma education of 1 respondent $(6.7 \%)$.

Based on the frequency distribution results above, it shows that respondents in Sumberjaya Village, Cihaurbeuti District, Ciamis Regency, four respondents (26.7\%) have jobs, 11 respondents $(73.3 \%)$ do not have jobs.

\section{Knowledge level}

Respondent's knowledge was measured by ten questions that included various kinds of drugs for pregnancy and lactation, the dangers of teratogenic drugs, and the impact caused when the use of drugs for pregnancy and breastfeeding was used irrationally.

The results of the univariate analysis of the pretest and posttest knowledge levels comparison in table 8 , in the excellent category from the total frequency of $2(13.3 \%)$ to $9(60.0 \%)$, the excellent category from the total frequency of $4(26.7 \%)$ to $6(40.0 \%)$, and the less category with the number of pretest frequencies $9(60.0 \%)$ being $0 \%$. The univariate analysis results obtained in table 9 , in the excellent category from the total frequency of $3(20.0 \%)$ to $13(86.7 \%)$, the good category and the less category from the total frequency of $6(40.0 \%)$ to $2(13,3 \%)$.

Based on table 10, the Mann-Whitney test shows that the counselling results using flipchart media, good knowledge increased from $9.67 \pm 0.14$ to $21.33 \pm 0.32$ and obtained a pre and post value of 0.000 .

Based on table 11, the Mann-Whitney test showed that the results of good knowledge increased from $10.50 \pm 0.15$ to $20.50 \pm 0.30$ and obtained a pre and post $p$-value of 0.001 .

\section{Relationship level of knowledge with educational characteristics}

Based on table 12, showing the results of calculations using the Spearman test, the pretest $p$ value was 0.732 , and the posttest $p$-value was 0.253 . Table 13 shows the calculation results obtained p-value pretest and posttest of $0.033(p<0.05)$.

The normality test results of the knowledge variables of the pre and post-KolmogorovSmirnov data showed a p-value $<0.05$. In comparison, the homogeneity test with the Levene test obtained the value of sig $=0.000$.

Data analysis using the Wilcoxon Signed Rank Test obtained a p-value of 0.003 . 


\section{DISCUSSION}

\section{Knowledge level reliability test}

Based on the calculation results, it is found that the $r$ value for each knowledge level question is more excellent than the $r$ table, then the knowledge level questionnaire is declared valid as in table 1.

\section{Knowledge level reliability test}

A questionnaire can be declared reliable if the value of Chronbach's alpha obtained is more significant than 0.6. Furthermore, based on the questionnaire analysis, it was found that Chronbach's alpha value $>0.6$, it can be said that the knowledge questionnaire item was reliable.

\section{Characteristics of Respondents}

Age has a significant influence on the health behaviour of pregnant women, especially in the third trimester of pregnancy. This study follows the theory put forward by Komariah (Komariah \& Nugroho, 2020) that a person's ability to respond to information can be influenced by age. The data results on the frequency distribution of pregnant women respondents according to age group, namely the age of 20-27 years, more than nine respondents $(60.0 \%)$ came to attend the counselling and aged 28-35 years, namely six respondents (40.0\%). According to the statistics collected, the percentage of pregnant and nursing mothers in Sumberjaya Village aged 20-27 years is between 53.3 and $60.0 \%$. Age is one of the factors that can determine the success or failure of counselling about the use of pregnancy and breastfeeding drugs. Scales (Scales et al., 2016) can state that when they are old enough, a person's level of maturity and strength will be more mature in thinking and working. Then through knowledge that has been previously owned, own experience, the experience of others, environment and other intrinsic factors can shape one's knowledge in the long term and will last until old age.

Based on the data seen in the frequency distribution of respondents according to education, namely elementary education as many as six respondents $(40.0 \%)$, junior high school education who attended counselling the most were seven respondents $(46.7 \%)$, high school education two respondents (13.3\%), and education diploma 0 respondents. The same thing was expressed by Pratiwi (Pratiwi et al., 2016), that the level of education of a person or individual will affect the process and ability to think to capture new information. The latest education level in Sumberjaya Village, Cihaurbeuti District, Ciamis Regency, has the highest percentage, are junior high school education at $40.0 \%$ for pregnant women and $46.7 \%$ for breastfeeding mothers. This condition can be because the majority of the people have lower middle economic levels and do not prioritize continuing to higher education. They tend to pay more attention to the health of themselves and their families.

\section{Knowledge level}

The results of the distribution of the working frequency of breastfeeding mothers show that respondents in Sumberjaya Village, Cihaurbeuti District, Ciamis Regency, there are seven respondents (46.7\%) who have a job, eight respondents (43.3\%) do not have a job. The most significant percentage of this characteristic is $73.3 \%$, and $46.7 \%$ of respondents do not work (as housewives), which means a non-significant relationship between the level of knowledge and work. According to research by Rojatz (Rojatz et al., 2017), the occurrence of the level of knowledge is influenced by experience, the primary abilities, which include flexibility, creativity, the ability to change, and the desire to continue learning.

The results of the univariate analysis about pretest and posttest knowledge indicate differences in the level of knowledge before and after being given counselling using flipchart media. Most pregnant and lactating mothers have a good level of knowledge after being given counselling. This condition follows what Anam (Anam et al., 2018) stated: the better knowledge a person has, the more comprehensive the insight he has, including his knowledge about the use of pregnancy and breastfeeding drugs. 
Respondents' knowledge change from before being given a flipchart and after being given a flipchart, that after giving counselling with flipchart media there is a change in respondents' knowledge from before being given a flipchart and after being given a flipchart.

\section{Relationship level of knowledge with educational characteristics}

From the results of the calculation of the relationship between education level and knowledge, it can be seen that there is a relationship between the education level of pregnant women and knowledge in Sumberjaya Village Cihaurbeuti District, Ciamis Regency.

Based on the theory that formal education has a considerable influence on one's knowledge, if someone is highly educated, it will have high knowledge and vice versa if someone has common knowledge will have shared knowledge and will influence understanding something. However, it should be emphasized that someone with low education is not low in knowledge, where knowledge or information can be obtained formally and informally.

Giving flipcharts on respondents' level of knowledge in Sumberjaya Village, Cihaurbeuti District, Ciamis Regency, the Kolmogorov Smirnov test was carried out, it was found that the data were not normally distributed with a Sig value $>0.0$. In comparison, the homogeneity test with the Levene test showed that the data was not homogeneous with $\mathrm{Sig}<0.05$.

Wilcoxon test results from pretest and posttest data on knowledge of pregnant and lactating mothers about the use of drugs before and after counseling using flipchart media with a $p$-value of $0.003(p<0.05)$, which means that there is an additional effect of counseling with flipchart media on mother's knowledge pregnant and lactating women about the use of drugs in Sumberjaya Village.

According to Barley (Barley et al., 2017), knowledge of a person's sensing results is usually obtained from experience from various sources such as mass media, electronic media, health workers, poster media, relatives. This knowledge can form certain beliefs so that a person behaves following these beliefs.

According to Zheng (Zheng et al., 2019) research, several aspects need to be considered regarding drug prescribing for breastfeeding mothers. One of them is by providing information to breastfeeding mothers to observe the baby's movements which can be associated with the occurrence of side effects such as changes in the baby's diet, changes in the baby's sleep pattern, the baby is restless or restless, and digestive disorders. Knowledge about the use of drugs during pregnancy and breastfeeding will have consequences for the fetus and baby. The problems faced if pregnant and lactating women do not use drugs correctly will increase fetal defects, congenital disabilities, and the lack of good baby growth. So it is vital to do counselling to pregnant and lactating women about the use of pregnancy and breastfeeding drugs to increase knowledge.

\section{CONCLUSIONS AND RECOMMENDATIONS}

Knowledge of pregnant and lactating mothers before counselling had a level of knowledge in the category of less. After counselling using flipchart media, the knowledge of pregnant and lactating mothers increased to a good category.

There is a relationship between the education level of pregnant and lactating mothers with knowledge of pregnant and lactating mothers, and there are differences in knowledge of pregnant and lactating mothers about the use of drugs using flipchart media in Sumberjaya Village, Cihaurbeuti District, Ciamis Regency.

Suggestions need to be carried out again for further testing of knowledge results during pregnancy and breastfeeding.

\section{ACKNOWLEDGMENTS}

We express our gratitude to Allah Subhanahu Wa Ta'ala, and thank LPPM STIKes Muhammadiyah Ciamis, who have supported providing financing for the implementation of community service and all participants and parties from Sumberjaya Village, 
Cihaurbeuti District Ciamis Regency. They have supported the smooth running of counselling for pregnant and lactating mothers.

\section{REFERENCES}

Anam, A. K., Winarni, S., \& Winda, A. (2018). Upaya perawat dalam fase mitigasi bencana Gunung Kelud berdasarkan ICN framework. Jurnal Terapan, 4(2), 84-92.

Anita, A. (2017). Faktor Penyakit Infeksi, Penggunaan Obat dan Gizi Ibu Hamil terhadap Terjadinya Kelainan Kongenital pada Bayi Baru Lahir. Jurnal Kesehatan, 8(1), 120.

Barley, W. C., Treem, J. W., \& Kuhn, T. (2017). Valuing Multiple Trajectories of Knowledge: A Critical Review and Agenda for Knowledge Management Research. Academy of Management Annals, 12(1), 278-317.

Harun, N., Darmawan, E., \& Nurani, L. H. (2017). Effect of calyx capsule-ethanol extract Hibiscus sabdariffa L. on renal function of healthy volunteers. IOP Conference Series: Materials Science and Engineering, 259(1), 012019.

Komariah, S., \& Nugroho, H. (2020). Hubungan Pengetahuan, Usia Dan Paritas Dengan Kejadian Komplikasi Kehamilan Pada Ibu Hamil Trimester lii Di Rumah Sakit lbu Dan Anak Aisyiyah Samarinda. KESMAS UWIGAMA: Jurnal Kesehatan Masyarakat, 5(2), 83.

Maulana, I., S, S., Sriati, A., Sutini, T., Widianti, E., Rafiah, I., Hidayati, N. O., Hernawati, T., Yosep, I., H, H., Amira D.A, I., \& Senjaya, S. (2019). Penyuluhan Kesehatan Jiwa untuk Meningkatkan Pengetahuan Masyarakat tentang Masalah Kesehatan Jiwa di Lingkungan Sekitarnya. Media Karya Kesehatan, 2(2), 218-225.

Pratiwi, H., Nuryanti, N., Fera, V. V., Warsinah, W., \& Sholihat, N. K. (2016). Pengaruh Edukasi Terhadap Pengetahuan, Sikap, Dan Kemampuan Berkomunikasi Atas Informasi Obat. Kartika Jurnal IImiah Farmasi, 4(1), 10-15.

Raikar, K., Thakur, A., Mangal, A., Vaghela, J. F., Banerjee, S., \& Gupta, V. (2020). A study to assess the effectiveness of a nutrition education session using flipchart among schoolgoing adolescent girls. Journal of Education and Health Promotion, 9, 183.

Ratih, I. A. D. K., \& Yudita, W. H. (2019). Hubungan tingkat pengetahuan tentang cara memelihara kesehatan gigi dan mulut dengan ketersediaan alat menyikat gigi pada narapidana kelas IIB Rutan Gianyar tahun 2018. Jurnal Kesehatan Gigi, 6(2), 23-26.

Rojatz, D., Merchant, A., \& Nitsch, M. (2017). Factors influencing workplace health promotion intervention: a qualitative systematic review. Health Promotion International, 32(5), 831839.

Scales, P. C., Benson, P. L., Oesterle, S., Hill, K. G., Hawkins, J. D., \& Pashak, T. J. (2016). The dimensions of successful young adult development: A conceptual and measurement framework. Applied Developmental Science, 20(3), 150-174.

Zheng, T., Yao, D., Chen, W., Hu, H., Ung, C. O. L., \& Harnett, J. E. (2019). Healthcare providers' role regarding the safe and appropriate use of herbal products by breastfeeding mothers: $A$ systematic literature review. Complementary Therapies in Clinical Practice, 35, 131-147. 


\section{APPENDIX}

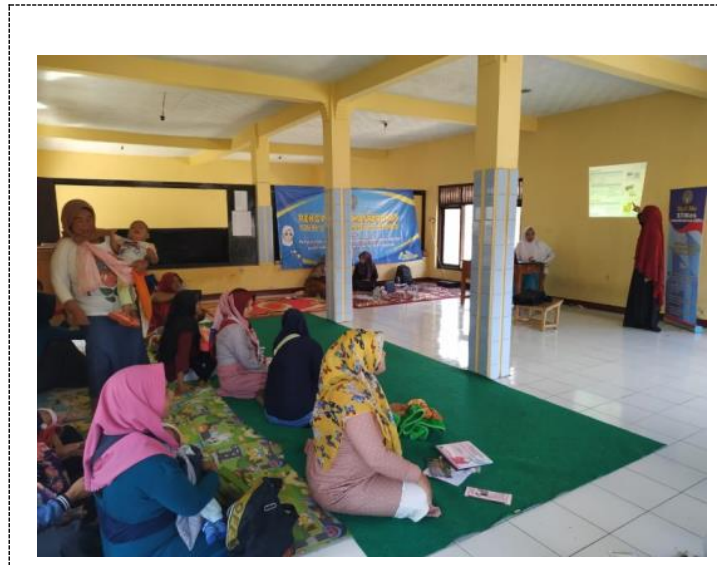

Figure 1. Pregnant and breastfeeding mothers counseling

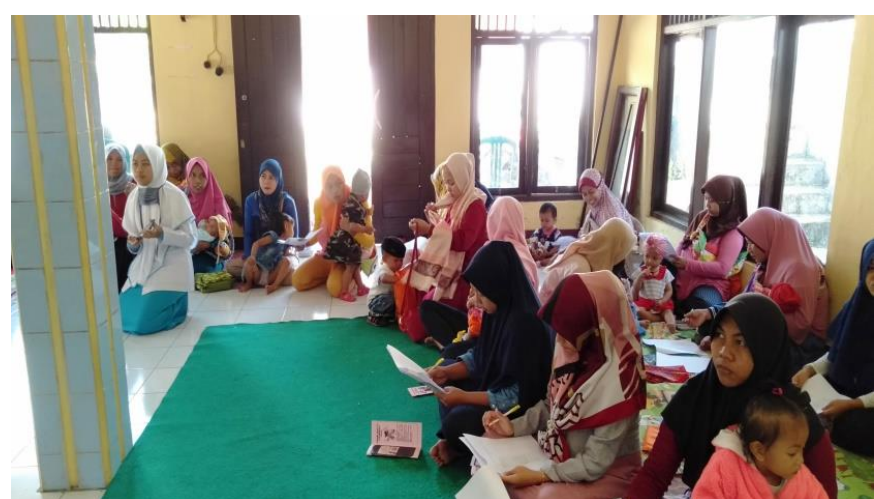

Figure 2. Pregnant and breastfeeding mothers pretest

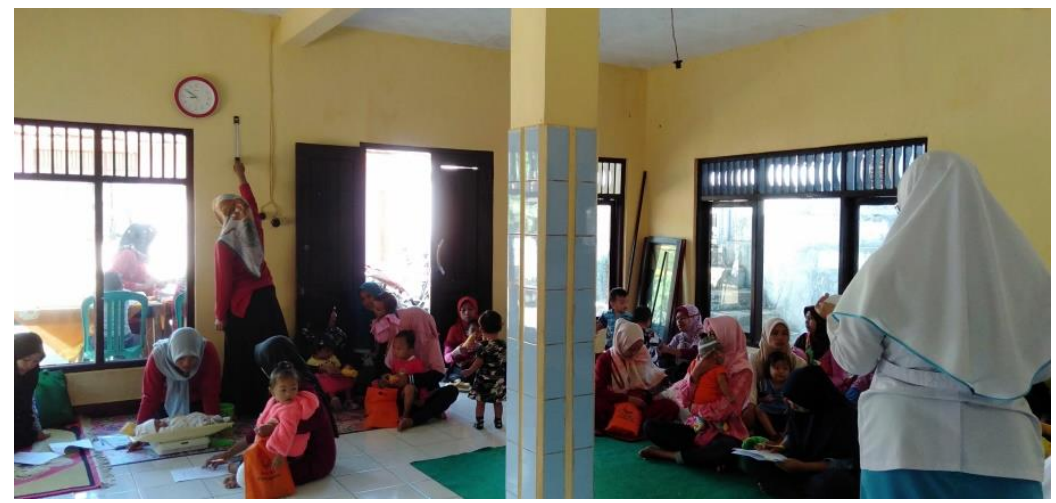

Figure 3. Pregnant and breastfeeding mothers posttest 